\title{
THE EFFECTIVENESS OF GAS RECOVERY SYSTEMS FOR MANAGING ODOUR FROM CONVENTIONAL EFFLUENT TREATMENT PONDS IN PALM OIL MILLS IN MALAYSIA
}

\author{
Andrew Yap Kian CHUNG ${ }^{1}$, Nastaein QAMARUZ ZAMAN ${ }^{2,3 *}$, Nurashikin \\ YAACOF $^{2}$, Syafinah YUSOFF ${ }^{2}$, Fatah Yah ABD. MANAF ${ }^{1}$, Rohaya \\ MOHAMED HALIM ${ }^{1}$ and Rusnani ABD. MAJID ${ }^{1}$ \\ ${ }^{1}$ Engineering \& Processing Division, Malaysian Palm Oil Board, 6 Persiaran Institusi, \\ Bandar Baru Bangi, 43000 Kajang, Selangor, Malaysia \\ ${ }^{2}$ School of Civil Engineering, Universiti Sains Malaysia, Engineering Campus, 14300 \\ Nibong Tebal, Pulau Pinang, Malaysia \\ ${ }^{3}$ Solid Waste Management Cluster, Universiti Sains Malaysia, Engineering Campus, \\ 14300 Nibong Tebal, Pulau Pinang, Malaysia
}

\section{Abstract}

Gas recovery systems at palm oil mills enable the curtailment of uncontrolled greenhouse gas emissions from open anaerobic pond, but can also reduce odour, an aspect which has not yet been substantiated. The objective of this study is to evaluate the odour emission from palm oil mill effluent and the effectiveness of covers and tank digester in reducing odour emission from the open lagoons. Odour samples were obtained from the cooling ponds in conjunction with in-field odour assessment performed on site. Results demonstrated that odour released from open ponding or covered lagoon were almost comparable, ranging from $33,150-162,000 \mathrm{OU} / \mathrm{m}^{3}$, and $68,705-102,000 \mathrm{OU} / \mathrm{m}^{3}$, respectively. In contrast, odour emission from cooling pond which used tank digester system seemed markedly lower, ranging between $13,000-76,000 \mathrm{OU} / \mathrm{m}^{3}$. In fact, the analysis of ambient air close to anaerobic tank digesters proved a reduction of odour emission to the surroundings (with $3.5 \mathrm{OU} / \mathrm{m}^{3}$, weak intensity) compared to open pond (with $2700 \mathrm{OU} / \mathrm{m}^{3}$, strong intensity) or covered lagoon (with $111 \mathrm{OU} / \mathrm{m}^{3}$, distinct

\footnotetext{
* Corresponding author: School of Civil Engineering, Universiti Sains Malaysia, Engineering Campus, 14300 Nibong Tebal, Pulau Pinang, Malaysia, e-mail: cenastaein@usm.my
} 
intensity). In conclusion, gas recovery systems at palm oil mills should be promoted not only towards the management of greenhouse gaseous, but also as an odour impact management strategy.

Keywords: odour impact, palm oil mill, anaerobic pond, palm oil mill effluent

\section{INTRODUCTION}

Malaysia is the second largest producer of palm oil, exporting 16.05 million tonnes of palm oil, equivalent to $36.78 \%$ of the global palm oil trade in 2016 (Kushairi et. al., 2018). The production of palm oil requires sterilization, clarification and hydrocyclone processes (Ohimain and Izah, 2017) which consumes between $5-7.5$ tonnes of fresh water for each tonne of crude palm oil milled (Ahmad et al., 2003; and Wu et. al., 2009). Of that water intake, about $50 \%$ will result in liquid waste (Ahmad et al., 2003; Awotoye et al., 2011), commonly known as palm oil mill effluent (POME).

Palm oil mill effluent is an acidic (3.4-5.2 pH), greasy $(130-18,000 \mathrm{mg} / \mathrm{l}$ oil and grease concentrations) liquid effluent, which is notoriously murky $(11,500-$ $79,000 \mathrm{mg} / 1$ total solids and $>500$ ADMI colour) when fresh. The untreated effluent is very hot $\left(80-90^{\circ} \mathrm{C}\right)$, highly organic with elevated BOD $(10,250-$ $43,750 \mathrm{mg} / \mathrm{l})$ and $\operatorname{COD}(15,000-100,000 \mathrm{mg} / \mathrm{l})$ (Bello et. al., 2013) concentrations. The discharging of palm oil mill effluent into water sources if left untreated, is detrimental to the environment, thus, is controlled in Malaysia under the Environmental Quality (Prescribed Premises) (Crude Palm Oil) (Amendement) Regulations 1982 (DOE, 1982).

Palm oil mill effluents are traditionally treated using open ponding system involving a series of open ponds including de-oiling tank, acidification ponds, anaerobic ponds and facultative or aerobic ponds. This conventional effluent treatment is well accepted due to its simplicity and reasonable effectiveness, about 95\% compliance (against $20 \mathrm{mg} / \mathrm{l}$ BOD discharge limit) after the final polishing step. However, the use of open anaerobic ponds emits uncontrolled methane reportedly in the average of $54.4 \%$ and at $1.5 \mathrm{l} / \mathrm{min} / \mathrm{m}^{2}$ to the atmosphere. Methane has a global warming potential of 25 as compared to $\mathrm{CO}_{2}$ (Hull, 2009). Not only that, the uncovered effluent treatment ponds led to rising odour complaints of 'foul' smell (Hassan and Abd-Aziz, 2015; Iwuagwu and Ugwuanyi, 2014) and 'bad' odour (Hassan et al., 2013). The effluent itself had elevated threshold odour number (TON) of 300 TON (Ahmad et. al., 2006) with reported odour emissions of $4,000-15,000 \mathrm{OU} / \mathrm{m}^{3}$ in concentration (Yaacof et al., 2017). Its characteristic palm oil mill effluent smell is so strong that the odour can be detected up to $1.5 \mathrm{~km}$ away from the mill, even reaching to about $5 \mathrm{~km}$ at times (Yaacof et al., 2017). 
Andrew Yap Kian CHUNG, Nastaein QAMARUZ ZAMAN, Nurashikin YAACOF, Syafinah YUSOFF, Fatah Yah ABD. MANAF, Rohaya MOHAMED HALIM,

Rusnani ABD. MAJID

In 2014, Malaysian Palm Oil Board (MPOB) imposed a new licence condition which mandates the installation of biogas capture system or methane avoidance facility to all new and expanding palm oil mills (MPOB, 2013). This new MPOB licensing requirement was initiated to curtail the uncontrolled emission of greenhouse gaseous into the atmosphere while at the same time harness renewable energy for the mills own energy consumption and that of others. Unfortunately, as of December 2016, only 92 biogas plants were completed, 9 under construction and 145 were still under planning (Loh et al., 2017). A significant portion, about $80 \%$ of the 445 palm oil mills in Malaysia still relied on the conventional open ponding. The continued usage of uncovered effluent ponds meant strong malodour were still a nuisance to its surrounding, as reported by several reports of odour episodes (Kasimon, 2017; Sulaiman 2017; and Khamis, 2017).

In Malaysia, odour pollution is regulated under the Environmental Quality Act 1974 (Act 127), Part IV Section 22, which restricts the emission of obnoxious or offensive odour (DOE, 1974). Clearly, in the case of palm oil mill effluent treatment, an additional angle, its odour emission need to be made aware, to further promote the installation of the gas capture systems. Until now, there are many information regarding different gas recovery technologies at palm oil mills including its effectiveness (Zinatizadeh et. al., 2017; Choi et al., 2013;), operation parameters (Ahmed et al., 2015; Jeong et al., 2014) and suppliers (Chin et. al., 2013). However, no such report can be found relating to their use in managing odour from effluent ponds.

Open anaerobic ponds, including those at palm oil mills, typically produce odorous hydrogen sulphide and ammonia gasses which are intermediate or end products of organic matter degradation by microbes under anaerobic condition. These odorous gases are further released to the atmosphere by the convective mass transfer mechanism for ammonia and the bubble-release process for hydrogen sulphide (Ni et al., 2009). In the case of the palm oil mill effluent, odour is stronger due to the fact that odour volatilisation and organic matter decomposition are increased by higher temperatures (Qamaruz-Zaman and Milke, 2012; Hugle and Kiel, 2001). Temperature of palm oil mill effluents typically is about $90^{\circ} \mathrm{C}$ (Mamimin et al., 2015; Krishnan et. al., 2016). The reduction in odour emissions can be achieved by covering the pond, which works by reducing the emitting area and its solar radiation as well as the wind velocity that transport the odorous emissions (Rahman and Borhan, 2012). Examples include natural covers such as straw, peat and biochar, to synthetic covers like polystyrene balls, synthetic sheet roof and geotextile covers, each with varying degree of ammonia $(24-90 \%)$, hydrogen sulphide $(30-90 \%)$, and odour $(40-90 \%)$ reduction efficiencies (Dougherty et al., 2017; Loyon et. al, 2016, Stenglein et al., 2011). 
Considering the lack of information regarding the odour issue at palm oil mills, a case study was commissioned involving three palm oil mills in Northern Malaysia. Each of these mills utilised a different effluent and gas recovery system; an open anaerobic pond, covered lagoon and tank digesters. The objective of this study is to identify the odour emission from a palm oil mill effluent pond and also establish odour mitigation efficiencies of the existing energy recovery systems at these mills. It is expected that the findings from this study would provide scientific evidence to mill operators and authorities alike on the dual capability of these technologies not only for energy production, but as importantly, towards odour management.

\section{METHODOLOGY}

\subsection{Location of the odour study}

This study was carried out at the palm oil mills as described in Table 1. The mills differed in terms of their effluent treatment system, which may influence odour emission from palm oil mill effluent.

Table 1. Brief Details of the Palm Oil Mills Involved in the Odour Assessment Study

\begin{tabular}{|c|c|c|}
\hline Mill identification & Location & $\begin{array}{c}\text { POME treatment } \\
\text { method }\end{array}$ \\
\hline Mill A & Padang Serai, Kedah & Open pond \\
\hline Mill B & Nibong Tebal, Penang & Covered lagoon \\
\hline Mill C & Batang Padang, Perak & Tank digester \\
\hline
\end{tabular}

Mill A had an approved processing capacity of 20 tons fresh fruit bunch (FFB) per hour (as of 2007), operating on an average of 16 hours per day, 312 days a year (TÜV Rheinland Japan Ltd, 2008).The wastewater is treated using conventional ponding system including acidification ponds, anaerobic ponds, and facultative, algae and settling ponds.

Mill B had a slightly higher capacity, processing 30 tonnes fresh fruit bunch (FFB) per hour (TUV-Rhein, 2008). The effluent treatment system was recently upgraded to covered anaerobic lagoon system. The anaerobic covered lagoon is incorporated into a biogas power plant that is able to generate $2.0 \mathrm{MW}$ energy and is currently at the final stages of certification for connectivity to Tenaga Nasional Berhad (Tisheva, 2017).

Mill C had the highest FFB processing capacity with 60 tons/hr (as of 2000) and expandable to 120 tons/hr. Five Continuous flow-Stirred Tank Reactors (CSTR) had displaced the original wastewater treatment system which consisted 
Andrew Yap Kian CHUNG, Nastaein QAMARUZ ZAMAN, Nurashikin YAACOF, Syafinah YUSOFF, Fatah Yah ABD. MANAF, Rohaya MOHAMED HALIM,

Rusnani ABD. MAJID

of 6 open anaerobic lagoons. In the upgraded effluent treatment system, raw POME was screen filtered and pumped from the cooling/acidification pond to the Anaerobic Digester Feeding Tank. Thereafter, the raw POME from the Feeding Tank was fed uniformly via the Distribution System to one unit $3,000 \mathrm{~m}^{3}$ tank with floating roof and four units $3,700 \mathrm{~m}^{3}$ tanks with fixed roofs for the generation and capture of biogas. Designed hydraulic retention time (HRT) was 17.88 days for an average POME flow of $1000 \mathrm{~m}^{3} / \mathrm{d}$.

\subsection{Background of odour study}

The odour study included sampling activities at the acidification/cooling ponds for all palm oil mills. Four odour samples were collected from the same pond over a course of three days. All samples were analysed at Universiti Sains Malaysia (USM) Odour Laboratory within 30 hours. In addition to the sampling and laboratory assessment of samples from the pond, assessment of odour at the site was performed using an in-field olfactometer. In total, 4 on-site assessments were carried out near the anaerobic effluent treatment system (e.g. anaerobic pond, covered anaerobic lagoon and tank digester). The same on-site odor assessment location was monitored over three days.

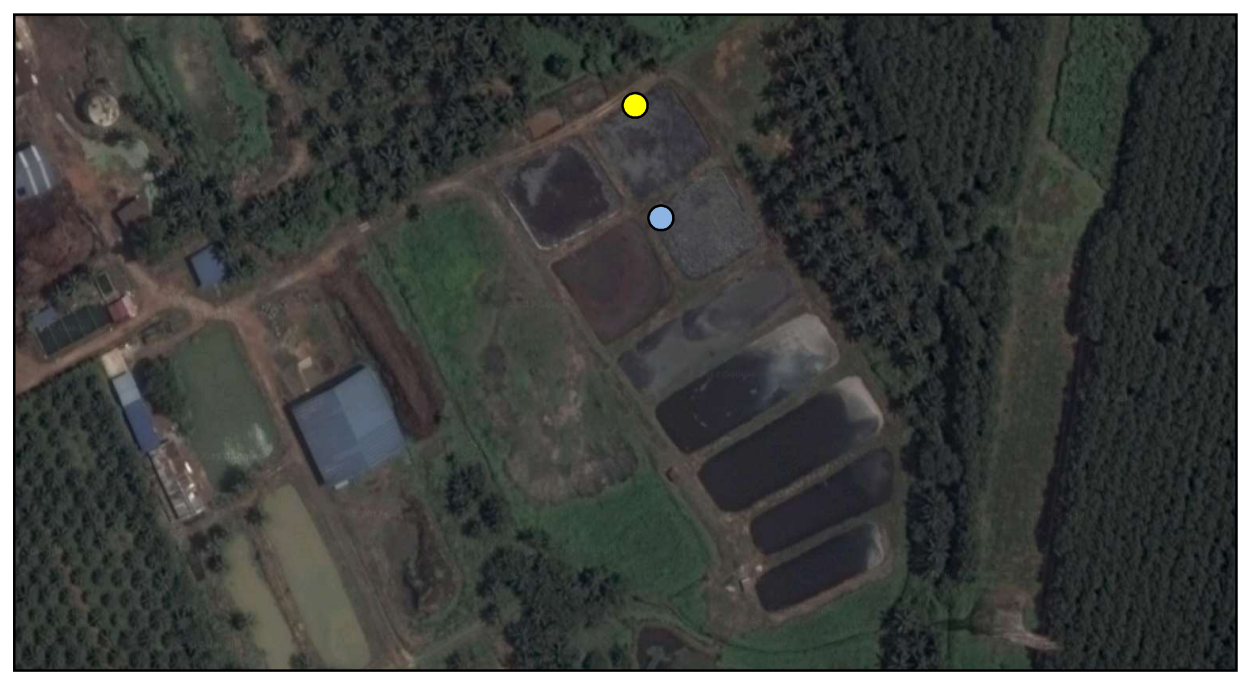

Fig. 1. The conventional ponding system for palm oil mill effluent treatment at Mill A. On-site odour assessment was performed nearby the anaerobic ponds (O), while odour samples were collected from the cooling pond ( $\triangle$, with an estimated size of $40 \mathrm{~m} \times 70 \mathrm{~m}=2800 \mathrm{~m}^{2}$ ) 
Figure 1 shows the layout of the treatment effluent system at Mill A and the locations involved in the study. Odour monitoring was performed twice; between $15^{\text {th }}-17^{\text {th }}$ August, 2016 and $28^{\text {th }}-30^{\text {th }}$ March, 2017.

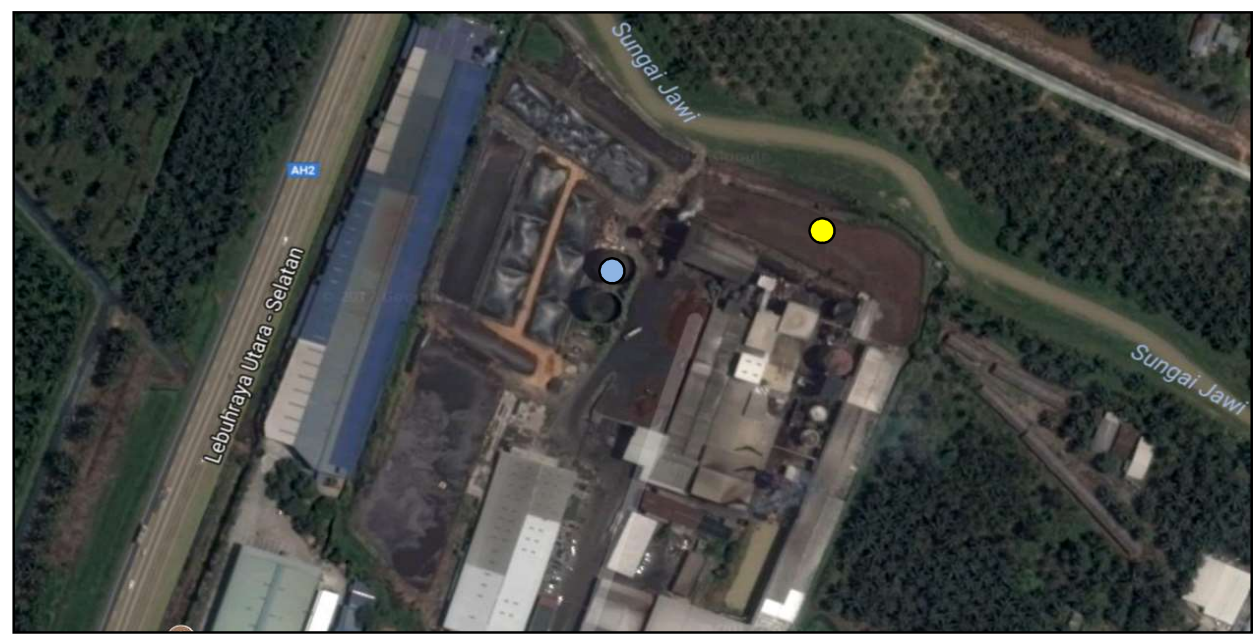

Fig. 2. The covered anaerobic lagoons at Mill B. On-site odour assessment was performed nearby the anaerobic ponds (๑), while odour samples were collected from the cooling pond $\left(\right.$, , with an estimated size of $161 \mathrm{~m} \mathrm{x} 30 \mathrm{~m}=4830 \mathrm{~m}^{2}$ )

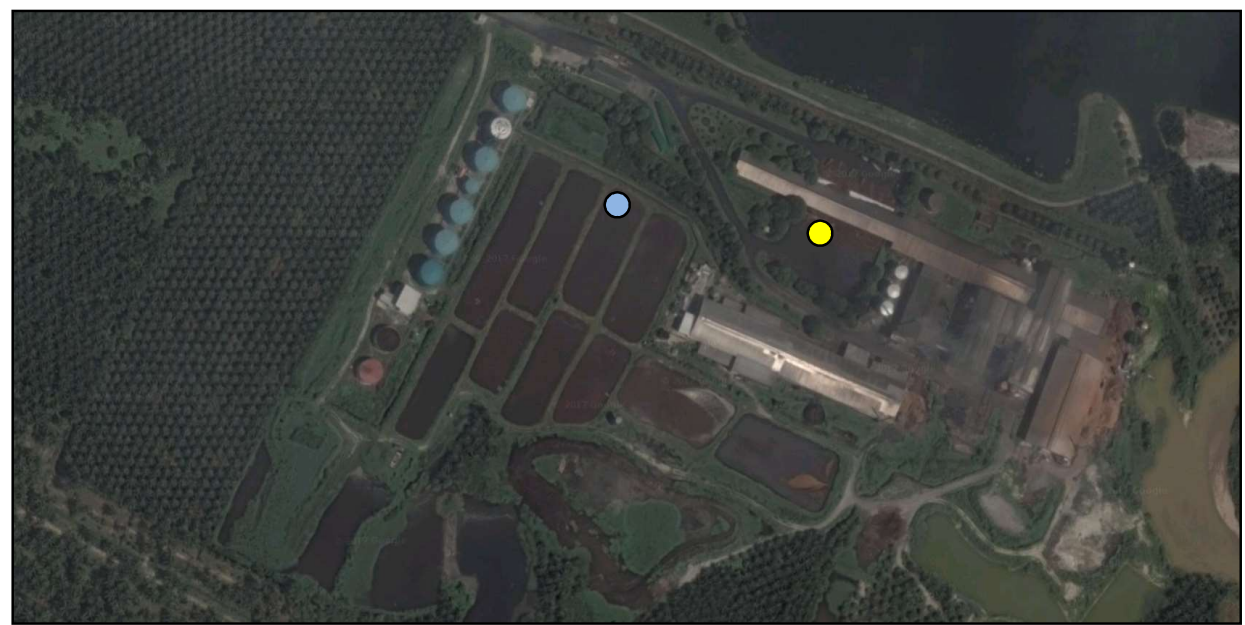

Fig. 3. The anaerobic tank digesters as part of the palm oil mill effluent treatment at Mill C. On-site odour assessment was performed nearby the anaerobic ponds ( $\odot$ ), while odour samples were collected from the cooling pond ( $\odot$, with an estimated size of $90 \mathrm{~m} \times 45 \mathrm{~m}=4050 \mathrm{~m}^{2}$ ) 
The layout of the effluent treatment system of Mill B is shown in Figure 2. Two odour monitoring sessions were carried out; between $26^{\text {th }}-28^{\text {th }}$ September, 2016 and $7^{\text {th }}-9^{\text {th }}$ February, 2017.

Mill $\mathrm{C}$ has an effluent treatment system as shown in Figure 3. Odour monitoring at the mill was conducted between $24^{\text {th }}-26^{\text {th }}$ October, 2016 and repeated from $21^{\text {st }}-23^{\text {rd }}$ February, 2017.

\subsection{Procedure of odour sampling and laboratory assessment}

A flux hood and vacuum chamber were used for odour sampling at the cooling pond, with samples collected into $10 \mathrm{~L}$ Nalophan bags. Odour samples were analysed at University Sains Malaysia Odour Laboratory at the School of Civil Engineering using a dynamic olfactometer (Scentroid SS400 Olfactometer, Canada) with a $12-16,667 \mathrm{OU} / \mathrm{m}^{3}$ detection limit. Sampling and assessment procedure was according to MS 1963: 2007 Air Quality - determination of odour concentration by dynamic olfactometry. All samples were tested within 30 hours of sample collection, and pre-dilution was at times necessary prior to analysis.

\subsection{Procedure of on-site odour assessment}

The method of odour assessment followed that of Balch et. al. (2015) and Bakhtari and Medina (2016) which were enhanced techniques adapted from the VDI3940 Grid Method (2006). The assessment involved the determination of odour concentration for a minimum of three readings within a 10 minutes period. The in-situ odour concentration was determined using an in-field olfactometer (SM 100 Scentroid Olfactometer, Canada), with detection limit of $3.5-11,355$ $\mathrm{OU} / \mathrm{m}^{3}$. In addition, the odour character was also noted during the assessment based on the UK Environment Agency (2007) odour descriptor. The use of field olfactometer (e.g. scentometer) for the evaluation of odour control applications at site has also been successfully implemented in the study by Regmi et al. (2007) on an operating swine lagoon.

\section{RESULTS AND DISCUSSIONS}

\subsection{Comparison of odour from effluent pre-treatment pond utilizing different downstream energy recovery system}

Figure 4 shows the odour concentration from the cooling ponds of all three mills during both odour survey runs. The lowest odour emission was from the cooling pond at Mill $\mathrm{C}$, ranging from $13,187 \mathrm{OU} / \mathrm{m}^{3}-76,276 \mathrm{OU} / \mathrm{m}^{3}$. In comparison, the 
effluent odour from Mill A and Mill B were higher between 29,247 OU/m $\mathrm{m}^{3}$ $161,896 \mathrm{OU} / \mathrm{m}^{3}$ and $44,800 \mathrm{OU} / \mathrm{m}^{3}-109,619 \mathrm{OU} / \mathrm{m}^{3}$, respectively. These POME odour in the ten thousand to hundred thousand values can be considered as extremely strong when compared to concentrations of $100-20,000 \mathrm{OU} / \mathrm{m}^{3}$ for wastewater treatment plant (Zarra et. al., 2014) or $245-4635 \mathrm{OU} / \mathrm{m}^{3}$ for swine barn exhaust fans (Zhou and Zhang, 2003). Interestingly, Zhou and Zhang (2003) also stressed that the variable odour emission was not influenced by swine rearing characteristics such as the type and years of operation, barn ventilation and manure handling system.

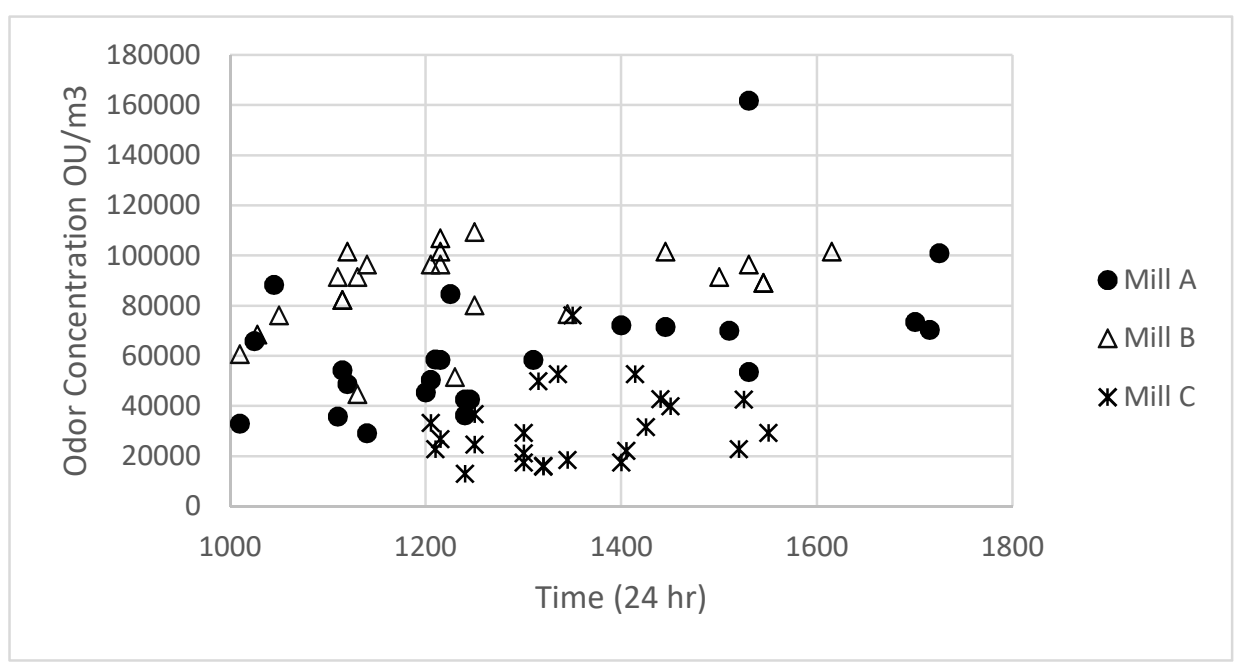

Fig. 4. Odour concencentration from cooling ponds at Mill A, Mill B and Mill C observed during both odour survey runs

The variation of odour data in this study happened because of the types of odour treatment used. The adoption of anaerobic tank digester at Mill $\mathrm{C}$ has the potential to reduce odour emission from cooling pond by as much as $65 \%$, which could be attributed to its more efficient effluent degradation. It has to be remembered that Mill A was still practicing the conventional open pond system. Mill B on the other hand, had a covered anaerobic lagoon system, but was still in its commissioning stage during the time of the odour survey. These circumstances may have contributed to the elevated odour concentrations, as a result of the conventional and less efficient effluent treatment. It would be beneficial to check on the potentiality of odour reduction from the cooling pond at Mill B when its covered lagoon is fully operational. Since this study include measurement from closed lagoon or closed tank, other factors that can affect the odour emission such as weather, wind and temperature can be neglected. 


\subsection{Odour control of various energy recovery system at Mills A, B and $\mathrm{C}$}

Figure 5 shows that odour emission was highest at the open anaerobic lagoon (Mill A) ranging from $2666 \mathrm{OU} / \mathrm{m}^{3}-4376 \mathrm{OU} / \mathrm{m}^{3}$, with an average median of $3419 \mathrm{OU} / \mathrm{m}^{3}$. Median values have also been reported by Liu et al. (2014) where odour emission is highly variable, e.g. ranging between $40-960 \mathrm{OU} / \mathrm{m}^{3}$ for concentrations at the edge of swine facilities. The highly odorous ambient air nearby the open anaerobic lagoon for Mill A correlates well with earlier observation of a strong odour from its effluent, at the pre-treatment (or cooling) pond. The effluent and detected odour at the surroundings both have the distinct palm oil mill effluent odour, which can be described as a mixture of thick smell of burnt, soury and sewery.

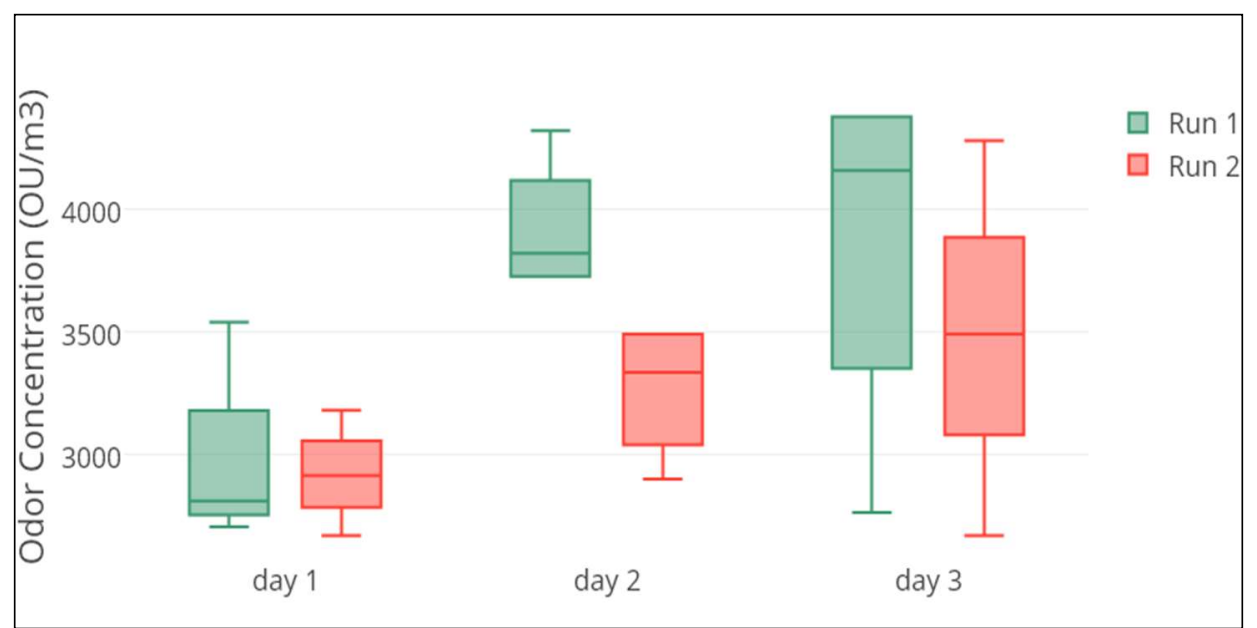

Fig. 5. Box-and-whisker plots of odour emission nearby an uncovered anaerobic pond at Mill A observed at different times. Each panel summarizes 4 measurements

Odour emission was also high at Mill B in its first run, as shown in Figure 6, when HDPE covers were still being installed over the anaerobic ponds. The median during the first run averaged at $2470 \mathrm{OU} / \mathrm{m}^{3}$, with an odour emission range of $2209 \mathrm{OU} / \mathrm{m}^{3}-2634 \mathrm{OU} / \mathrm{m}^{3}$. On the other hand, odour emission improved to between $124 \mathrm{OU} / \mathrm{m}^{3}-229 \mathrm{OU} / \mathrm{m}^{3}$, with an average median of $176 \mathrm{OU} / \mathrm{m}^{3}$ in the second run. The improved odour emission at the surrounding of the anaerobic pond at Mill B during the second run was due to the completion of HDPE covers over its anaerobic lagoon, although its energy recovery system was yet operational. The covers were able to reduce odour emission by about $95 \%$ compared to when anaerobic lagoon was uncovered. 


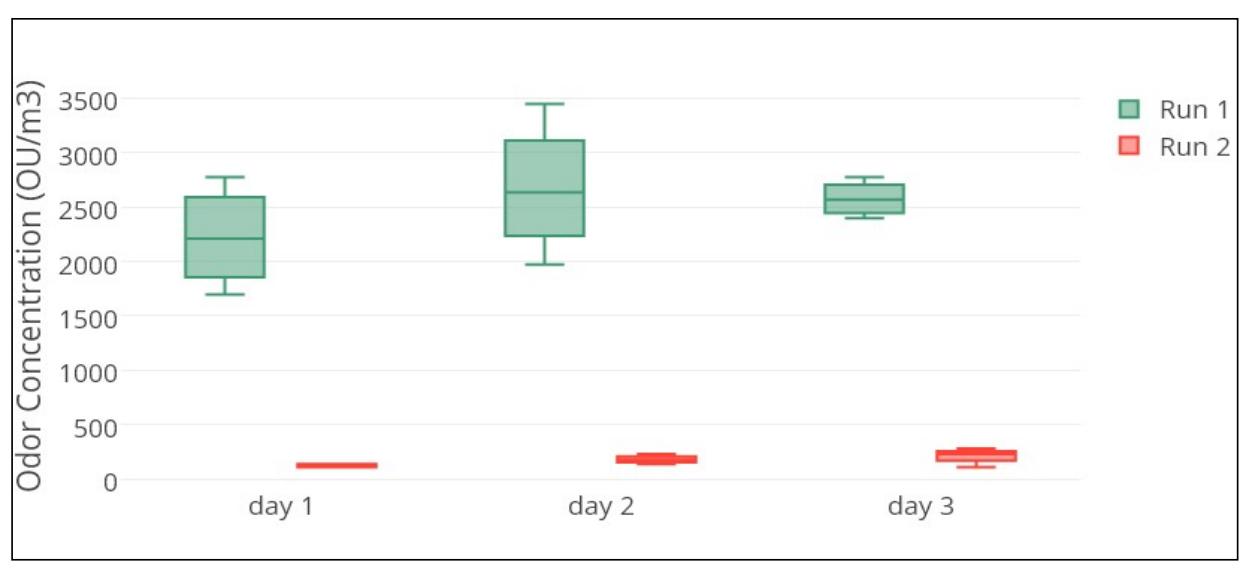

Fig. 6. Box-and-whisker plots of odour emission nearby a covered anaerobic lagoon at Mill B observed at different times. Each panel summarizes 4 measurements

That said, by far the most effective technique to reduce odour to the surrounding is by using closed anaerobic tank digesters as was practiced at Mill C. As shown in Figure 7 and Figure 8, the fully enclosed system achieved 99\% odour reduction, proving that an average of $4 \mathrm{OU} / \mathrm{m}^{3}$ is achievable (during both runs). A $7 \mathrm{OU} / \mathrm{m}^{3}$ limit at facility boundary is regulated in several US localities (e.g. Colorado, Connecticut and North Dakota) (Nicell, 2009), which indicates that the $4 \mathrm{OU} / \mathrm{m}^{3}$ would have been an acceptable odour emission. An odour exposure of $1 \mathrm{OU} / \mathrm{m}^{3}$ typically signifies the point of detection (very weak, not normally detected), $5 \mathrm{OU} / \mathrm{m}^{3}$ as faint odour (a person might be able to describe the odour) and $10 \mathrm{OU} / \mathrm{m}^{3}$ as distinct odour (DEFRA, 2010).

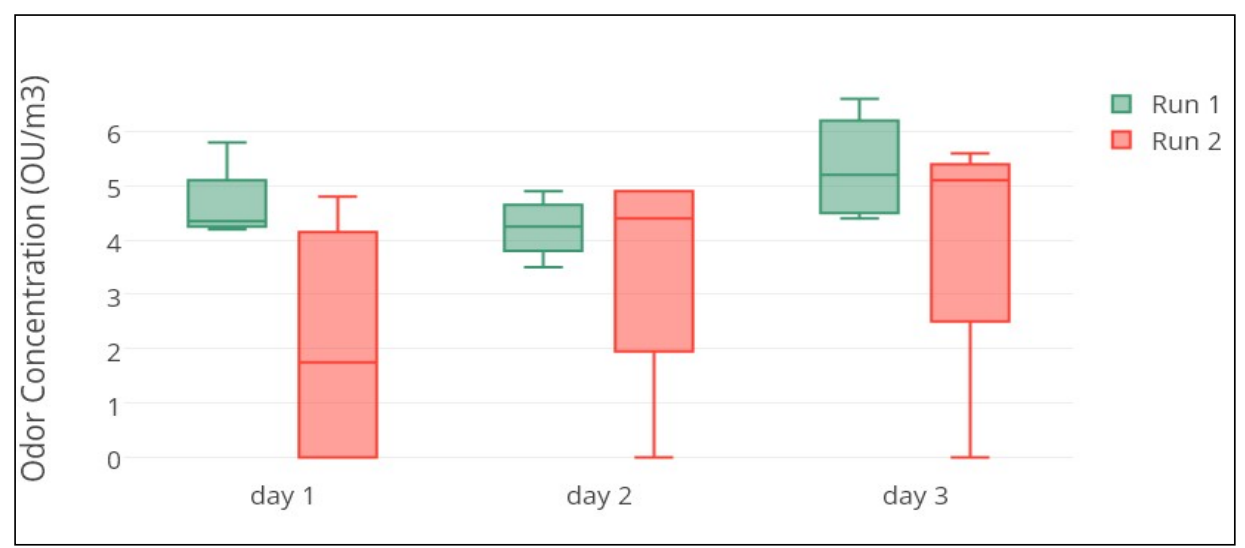

Fig. 7. Box-and-whisker plots of odour emission nearby an anaerobic tank digester at Mill $\mathrm{C}$ observed at different times. Each panel summarizes 4 measurements 


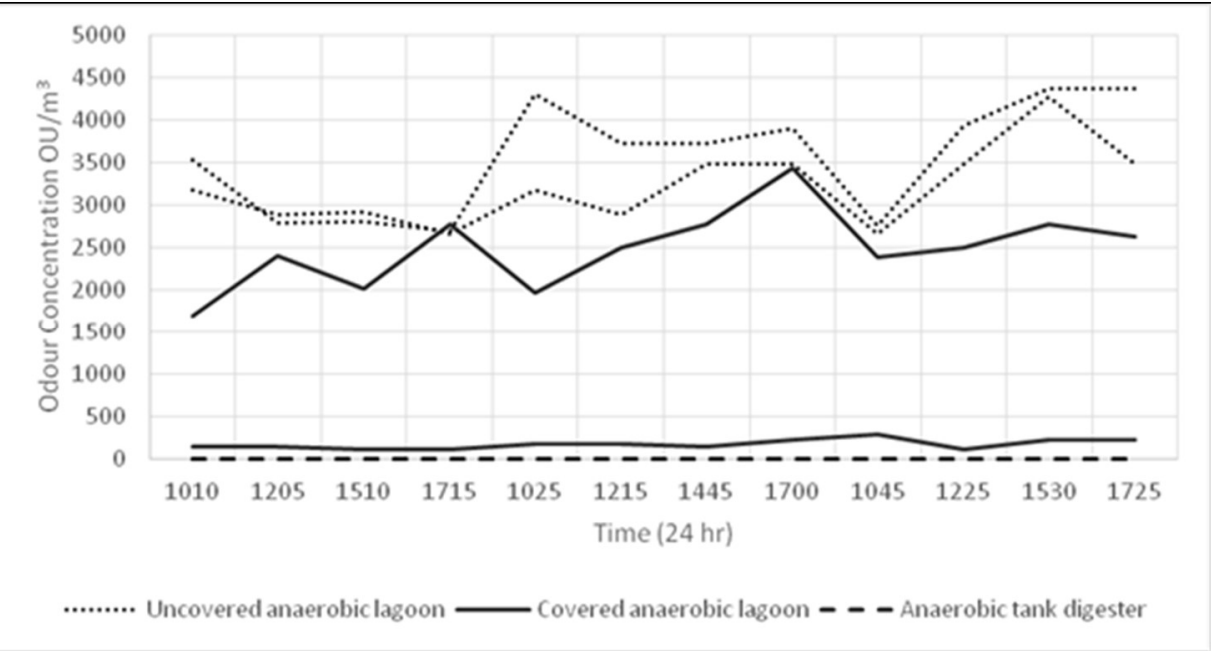

Fig. 8. Comparison of the three anaerobic effluent treatment systems at the mills towards odour emission mitigation to the surroundings/ambient

\section{CONCLUSION}

Cooling pond can emit between 13,187 - 161,896 OU/m3 odour, with the least being emitted when an enclosed tank digester was incorporated into its downstream effluent treatment. Anaerobic tank digesters are able to reduce odour emission by $99 \%$ compared to conventional open anaerobic pond. Covers are also able to reduce odour emission by about $95 \%$, with its efficiency partly influenced by the extent of lagoon covering, and its pressure release vents. Malodour from palm oil mill effluent can be mitigated by about $99 \%$ if the use of energy recovery systems at palm oil mills is also promoted as odour control measures. Besides anaerobic digester and covered lagoon, odour problem can be reduced by applying other methods such as catalytic oxidation, thermal incineration and absorption process (Biard et al. 2017; Schiavon et al., 2017). Those process are efficient in reducing malodour problem but others matters need to be taken into account such as its operation cost and maintenance.

\section{ACKNOWLEDGEMENT}

Funding: This research was supported by Malaysian Palm Oil Board, MPOB (Project No. EP181/2016: Measurement of Odour Emission Levels at Palm Oil 
Mills). Additional instrumental and technical support was provided by the Universiti Sains Malaysia, Odour Laboratory.

\section{CONFLICT OF INTEREST}

The authors declare that they have no conflict of interest.

\section{REFERENCES}

1. Ahmad, AL, Chong, MF, Bhatia, S and Ismail, S 2006. Drinking water reclamation from palm oil mill effluent (POME) using membrane technology. Desalination, 191(1), 35-44.

2. Ahmad, $A L$, Ismail, $S$ and Bhatia, $S$ 2003. Water recycling from palm oil mill effluent (POME) using membrane technology. Desalination, 157, 87-95.

3. Awotoye, OO, Dada, AC and Arawomo, GAO 2011. Impact of palm oil processing effluent discharging on the quality of receiving soil and rivers in South Western Nigeria. Journal of Applied Science and Research, 7(2), 11-8.

4. Bello, MM, Nourouzi, MM, Chuah Abdullah, L, Choong, TSY, Koay, YS and Keshani, S 2103. POME is treated for removal of color from biologically treated POME in fixed bed column: Applying wavelet neural network (WNN). Journal of Hazardous Materials, 262, 106-113.

5. Biard, PF, Couvert, A, and amp; Renner, C 2017. Intensification of volatile organic compound absorption in acompact wet scrubber at co-current flow. Chemosphere, 173, $612-621$.

6. Bull, M, McIntyre, A, Hakk, D, Allison, G, Redmore, J, Pullen, J, Caird, L, Stoaling, M and Fain, R 2014. IAQM Guidance on the assessment of odour for planning, Institute of Air Quality Management, London. Accessed on 20 April, 2018 at www.iaqm.co.uk/text/guidance/odourguidance-2014.

7. DEFRA 2010. Odour guidance for local authorities. Department for Environment, Food and Rural Affairs, United Kingdom.

8. Department of Environment 1974. Environmental Quality Act 1974. Accessed on 13 February, 2018 at https://www.doe.gov.my/portalv1/wpcontent/uploads/2015/01/Environmental_Quality_Act_1974_ACT_127.pdf

9. Department of Environment 1982. Environmental Quality (Prescribed Premises) (Crude Palm Oil) (Amendment) Regulations 1982. Accessed on 13 March, 2018 at https://www.doe.gov.my/portalv1/wpcontent/uploads/2015/01/Environmental_Quality_Prescribed_Premises_Cru de_Palm_Oil_Amendment_Regulations_1982_-_P.U.A_183-82.pdf. 
10. Department of Environment (DOE) 1977. Environmental Quality (Prescribed Premises) (Crude Palm Oil) Regulations, 1977. Percetakan Nasional Malaysia Berhad. Accessed on 14 March, 2018 at https://www.doe.gov.my/portalv1/wpcontent/uploads/2015/01/Environment al_Quality_Prescribed_Premises_Crude_Palm_Oil_Regulations_1977_P.U.A_342-77.pdf.

11. Dougherty, B, Gray, M, Johnson and Kleber, M 2017. Can Biochar Covers Reduce Emissions from Manure Lagoons While Capturing Nutrients? Journal of Environmental Quality Abstract - Waste Management, 46(3), 659-666.

12. Hassan, MA and Abd-Aziz, S 2015. Waste and Environmental Management in the Malaysian Palm Oil Industry in Palm Oil: Production, Processing, Characterization, and Uses edited by Oi-Ming Lai, Chin-Ping Tan, Casimir C. Akoh. Elsevier, 1 Sep 2015 - Technology \& Engineering.

13. Hassan, S, Kee, LS and Al-Kayiem, HH 2013. Experimental study of palm oil mill effluent and oil palm frond waste mixture as an alternative biomass fuel. Journal of Engineering Science and Technology, 8(6), 703 - 712.

14. Hügle, T and Kiel, HA 2001. Temperature and odour emissions from liquid manure. Landtechnik, 56 (1), 36 -37.

15. Hull, C 2009. GHG Lifetimes and GWPs For ozone-depleting substances and their replacements. Manitoba Eco Network. Accessed on 22 March, 2018 at http://climatechangeconnection.org/wpcontent/uploads/2014/08/GWP_AR4.pdf.

16. Iwuagwu, JO and Ugwuanyi, JO 2014. Treatment and Valorization of Palm Oil Mill Effluent through Production of Food Grade Yeast Biomass. Journal of Waste Management.

17. Kasimon, MN 2017. Resah bau busuk kilang sawit. Sinar Harian. Accessed on 29 February, 2018 at http://www.sinarharian.com.my/edisi/johor/resahbau-busuk-kilangsawit-1.687296.

18. Krishnan, S, Singh, L, Sakinah, M, Thakur, S, Wahid, ZA and Alkasrawi, M 2016. Process enhancement of hydrogen and methane production from palm oil mill effluent using two-stage thermophilic and mesophilic fermentation. International Journal of Hydrogen Energy, 41(30), 12888-12898.

19. Kushairi A, Soh Kheang Loh, Azman I, Elina Hishamuddin, Meilina OngAbdullah, Zanal Bidin Mohd Noor Izuddin, Razmah G, Shamala Sundram and Ghulam Kadir Ahmad Parveez 2018. Oil Palm Economic Performance in Malaysia and R\&D Progress in 2017. Journal of Palm Oil Research Vol. 30(2) June 2018 p. 163-195. DOI: https://doi.org/10.21894/jopr.2018.0030. 
20. Liu, Z, Powers, W and Mukhtar, S 2014. A review of practices and technologies for odor control in swine production facilities. Applied Engineering in Agriculture, 30(3), 477-492.

21. Loh, SK, Nasrin, AB, Mohamad Azri, S, Nurul Adela, B, Muzzammil, N, Daryl Jay, T, Stasha Eleanor, RA, Lim, WS, Choo, YM and Kaltschmitt, M 2017. First Report on Malaysia's experiences and development in biogas capture and utilization from palm oil mill effluent under the Economic Transformation Programme: Current and future perspectives. Renewable and Sustainable Energy Reviews, 74, 1257-1274.

22. Loyon, L, Guiziou, F, Picard, S and Saint-Cast, P 2016. Farm-Scale Applicability of Three Covers (Peat, Polystyrene Balls and Synthetic Sheet Roof) to Reduce Ammonia Emissions from Pig Slurry Storage. Agricultural Sciences, 7, 396-406.

23. Loyon, L, Guiziou, F, Picard, S, Cast, PS 2016. Farm-Scale Applicability of Three Covers (Peat, Polystyrene Balls and Synthetic Sheet Roof) to Reduce Ammonia Emissions from Pig Slurry Storage. Agricultural Sciences, 7, 396406.

24. Malaysian Palm Oil Board 2011. Malaysia oil palm statistics. Accessed on 10 April, 2018 at http://econ.mpob.gov.my/economy/ei_statistics_content.html.

25. Malaysian Palm Oil Board 2012. Oil palm and the environment. Accessed on 10 April, 2018 at http://www.mpob.gov.my/en/palm-info/environment/520achievements.

26. Malaysian Palm Oil Board 2013. Public consultation on mandatory installation of biogas facilities in palm oil mills. Accessed on 5 April, 2018 http://www.mpob.gov.my/images/stories/pdf/2013/biogas_eng.pdf.

27. Malaysian Palm Oil Board 2015. MPOB E-licensing. License application manual. Accessed on 27 February, 2018 at http://elicense.mpob.gov.my/infos/Panduan.html.

28. Malaysian Palm Oil Board 2016. Malaysian oil palm statistics 2015, 35th ed., MPOB, Ministry of Plantation Industries and Commodities.

29. Mamimin, C, Singkhala, A, Kongjan, P, Suraraksa, B, Prasertsan, P, Imai, T and O-Thong, S 2015. Two-stage thermophilic fermentation and mesophilic methanogen process for biohythane production from palm oil mill effluent. International Journal of Hydrogen Energy, 40(19), 6319-6328.

30. Ni, JQ, Heber, AJ, Sutton, AL and Kelly, DT 2009. Mechanisms of gas releases from swine wastes. Transactions of the ASABE, 52, 2013-2025.

31. Nicell, JA 2009. Assessment and regulation of odour impacts. Atmospheric Environment 43 (2009) 196-206. 
32. Ohimain, EI and Izah, SC 2017. A review of biogas production from palm oil mill effluents using different configurations of bioreactors. Renewable and Sustainable Energy Reviews, 70, 242-253.

33. Qamaruz Zaman, N, Yusup, Y and Yaacof, N 2016. Verification of Receptor Exposure to Palm Oil Mill Odor Using In-Field Olfactometer with Odor Characteristic. Chemical Engineering Transactions, 54.

34. Qamaruz-Zaman, N, Milke MW 2012. VFA and ammonia from residential food waste as indicators of odor potential. Waste Management, 32(12), 242630 .

35. Rahman, S and Borhan, MS 2012. Typical odor mitigation technologies for swine production facilities: A review. Journal of Civil Environmental Engineering, 2(4), 117.

36. Rahmat Khamis, MF 2017. Lega kilang tutup, bau pun hilang. Harian Metro. Accessed on 29 February, 2018 at https://www.hmetro.com.my/mutakhir/2017/06/239698/lega-kilang-tutupbau-pun-hilang.

37. Regmi, S Ongwandee, M, Morrison, G, Fitch, M and Surampalli, R 2007. Effectiveness of Porous Covers for Control of Ammonia, Reduced Sulfur Compounds, Total Hydrocarbons, Selected Volatile Organic Compounds, and Odor from Hog Manure Storage Lagoons, Journal of the Air \& Waste Management Association, 57(6), 761-768.

38. Schiavon, M, Schiorlin, M, Torretta, V, Brandenburg, R end amp, Ragazzi, M 2017. Non-thermal plasma assisting the biofiltration of volatile organic compounds. Journal of Cleaner Production, 148, 498-508.

39. Stenglein, RM, Clanton, CJ, Schmidt, DR, Jacobson, LD and Janni, KA 2011. Permeable Covers for Odor and Air Pollution Mitigation in Animal Agriculture - A Technical Guide. Air Quality Education in Animal Agriculture. USDA National Institute of Food and Agriculture. Accessed on 14 April, 2018 at https://articles.extension.org/sites/default/files/PermeableCovers\%20FINAL 0.pdf.

40. Sulaiman, NA 2017. JAS diarah siasat 2 kilang sawit. Khamis. Berita Harian. Accessed on Accessed on 29 February, 2018 at https://www.bharian.com.my/node/255139.

41. Wu, TY, Mohammed, AW, Jahim, JM and Anuar, N 2009. A holistic approach to managing palm oil mill effluent (POME): biotechnological advances in the sustainable reuse of POME. Biotechnology Advances, 27, 4052. 
42. Yaacof, N, Qamaruz Zaman, N and Yusup, Y 2017. Comparison Method of Odour Impact Evaluation Using Calpuff Dispersion Modelling and On-Site Odour Monitoring. Galeri Warisan Kejuruteraan, 1(2), 1-5.

43. Yacob, S, Hassan, MA, Shirai, Y, Wakisaka, M and Subash, S 2006. Baseline study of methane emission from anaerobic ponds of palm oil mill effluent treatment. Science of the Total Environment, 366, 187-96.

44. Zarra T, Reiser M, Naddeo V, Belgiorno V, Kranert M 2014. Odour emissions characterization from wastewater treatment plants by different measurement methods. Chemical Engineering Transactions, 40, 37-42.

45. Zhou, X and Zhang, Q 2003. Measurements of odour and hydrogen sulfide emissions from swine barns. Canadian Biosystems Engineering, 45, $6.13-$ 6.18 .

Editor received the manuscript: 12.08.2019 